\title{
AWARENESS OF FAMILY PLANNING AMONG THE AGRICULTURE LABOUR WOMEN - A SOCIOLOGICAL STUDY
}

\author{
Drakshayani P. Kongawad ${ }^{1}$, G. K. Boodeppa²
}

\section{HOW TO CITE THIS ARTICLE:}

Drakshayani P. Kongawad, G. K. Boodeppa. "Awareness of Family Planning among the Agriculture Labor Women - A Sociological Study". Journal of Evolution of Medical and Dental Sciences 2014; Vol. 3, Issue 08, February 24; Page: 1850-1854, DOI: 10.14260/jemds/2014/2068

ABSTRACT: The Government of India launched a family welfare programme, whose main objective is to spread the knowledge of family planning method and develop among the people and attitude favorable for adoption of contraceptive method several KAP studies have been conducted. The present study was conducted in Batakurki village, which is at the distance of $20 \mathrm{~km}$ from Ramdurg city. The present paper is an effort to assess the knowledge, attitude and practice of family planning (KAP) among the Batakurki agriculture labor women. The findings show that the maximum educational level of the respondents is illiterate. Since agriculture is the primary occupation they are agriculture laborers which accounts for 100 percent. Their income ranges from Rs 5, 00 to 25, 00.75 percent of the respondents had the knowledge of tubectomy. Tubectomy is the most popular method in the study villages.

INTRODUCTION: In the early 1950s, the Government of India launched a family welfare programme. This programme is to accelerate the country's economic and social development, and has formulated an official policy with the aim of reducing the rate of population growth. The programme was accorded special priority during the 1960s and 1970s, but so far only met with marginal success, that is till 1989-1990, only 41.9 percent of the total eligible couple has been effectively protected. ${ }^{1}$

Family planning through contraception tries to achieve two main objectives; firstly, to have only the desires number of children and secondly, to have these children by proper spacing of pregnancies. $^{2}$ Mass media also plays an important role in promotion and acceptability of contraception..$^{3,4}$

Since the inception of the programme several knowledge, attitude and practice studies have been conducted. Earlier KAP studies were conducted on small sample of specific population and were more descriptive in character. In the late 1960s, scales were developed and utilized in KAP surveys, sample size increased and studies were done concerning he correlates of knowledge, attitude and practice of family planning. Knowledge and practice of family planning is strongly relates to higher level of education, to labor force participation, to fertility.

One of the main objectives of the programme is to spread the knowledge of family planning method and develop among the people and attitude favorable for adoption of contraceptive method. The progress achieved in this sphere is normally assessed from the result of KAP Survey. ${ }^{5}$

In most of the studies, it was found that education is the prime influencing factor. It may have a direct influence on fertility, since education affects the attitudinal and behavioral patterns of the individuals. A number of K.A.P. survey has been carried out covering different population groups. In their study among rural Rajputs and SCs found that raise in education besides providing knowledge and the contraceptive method helps in improving acceptance of family control devices. ${ }^{6}$ There are also other studies carried out in this sphere.7-9 
In recent years, the need for such kind of studies was very important because more specific knowledge can be acquired about factor that determines the fertility and family acceptance. This in turn can be used to develop suitable programme for them. ${ }^{10}$

The present paper is an attempt to knowledge, attitude and practice of family planning (KAP) among the Batakurki village of agriculture labor women.

MATERIAL AND METHOD: The present study is based on data collected at Random sampling as a lottery method from 100 married women from the Batakurki village and lies at a distance of $20 \mathrm{~km}$ from the Ramdurg city.

The primary data has been collected with an interview schedule. For the collection of the data, female investigators were agriculture labor women.

RESULTS AND DISCUSSION: Socio- demographic characteristics of the 100 married Batakurki women interviewed, such as current age, level of education occupation and income at the time of the survey are presented in Table 1.

\begin{tabular}{|c|c|c|}
\hline Characteristics & No-100 & Percentage \\
\hline 1. Present age (in year) & & \\
\hline $15-24$ & 43 & $43 \%$ \\
\hline $25-34$ & 47 & $47 \%$ \\
\hline $35-44$ & 10 & $10 \%$ \\
\hline 2. Level of Education & & \\
\hline Illiterate & 74 & $74 \%$ \\
\hline Primary & 21 & $21 \%$ \\
\hline H. secondary & 04 & $04 \%$ \\
\hline PUC & --- & --- \\
\hline 3. Occupation & --- & --- \\
\hline Agriculturist & --- & --- \\
\hline Business & --- & --- \\
\hline Agr. Labors & 100 & $100 \%$ \\
\hline 4. Annual Income & & \\
\hline $5000-10,000$ & & \\
\hline $10,001-15,000$ & 06 & $06 \%$ \\
\hline $15,001-20,000$ & 40 & $40 \%$ \\
\hline $20,001-25000$ & 52 & $52 \%$ \\
\hline 25,001 above & --- & -- \\
\hline
\end{tabular}

Table 1: Demographic characteristics of the study population

It is seen from the table that the current age of the married women ranged from 15-44 years. 47 percent of these women are in the age groups of 25-34 years; 43 percent in the age groups of 1524 years; 10 percent in the age groups of 35-44 years respectively. 
As for the level of education, it is seen from the table that 74 percent of the women are illiterate. 21 percent of them primary education; 04 percent of them died their metric.

It is also seen that 100 percent of the respondents are farmers. Because, agriculture is primary occupation.

52 percent of the respondents have an income in the range of Rs 20,001-25, 000; 40percent of the respondents has an income in the range of Rs15, 001-20, 000; 06 percent of the respondents have an income in the range of Rs 10, 001-15, 000; 02 percent of the respondents used to be in the range of Rs. 25, 001 above.

Table-2 shows the distribution percentage of the respondents with knowledge of different family planning method by age group. It indicates that family planning knowledge was widespread, and that all the respondents were aware of at least one method of tubectomy is more popular among the women who reported knowledge of the contraceptive method. As it can be seen from the table that.

Knowledge of various family planning methods.

\begin{tabular}{|c|l|c|c|}
\hline Sl. No. & \multicolumn{1}{|c|}{ Methods } & No. of respondents & Percentage \\
\hline 1. & Tubectomy & 05 & $05 \%$ \\
\hline 2. & Tubectomy, oral pill & 75 & $75 \%$ \\
\hline & Copper-T & --- & -- \\
\hline 3. & Tubectomy, copper-T & 20 & 20 \\
\hline & Oral pill, condom & --- & --- \\
\hline 4. & $\begin{array}{l}\text { Tubectomy, copper-T, Oral pill, } \\
\text { Condom, Diaphragm/rhythm Withdrawal. }\end{array}$ & --- & --- \\
\hline
\end{tabular}

Table 2: Distribution (\%) of respondents with knowledge of family planning methods

75 percent of respondents' knowledge about tubectomy, oral pill, copper-T. 20 percent of respondents known about methods like tubectomy, copper-T, oral pill, Condom. 05 percent of respondents known about only tubectomy.

Table-3: It is seen that main source of knowledge, about different contraceptive methods known is "friends and neighbors" as reported by 63 percent of the respondents came to know about these methods through husband and relatives, 11 percent of the respondents came to know about these methods through health worker, 06 percent of the respondents came to know about these methods through doctors. It is followed by mass media with 05 percent respectively.

\begin{tabular}{|c|l|c|c|}
\hline Sl. No & Source of family planning & No. of respondents & percentage \\
\hline 1 & Husband/Relatives & 15 & $15 \%$ \\
\hline 2 & Neighbors/ friends & 63 & $63 \%$ \\
\hline 3 & Doctors & 06 & $06 \%$ \\
\hline 4 & Health worker & 11 & $11 \%$ \\
\hline 5 & Mass media & 05 & $05 \%$ \\
\hline
\end{tabular}

Table 3: Distribution (\%) of sources of knowledge, about family planning 
Table-4: It shows that 37 percent of respondents are satisfied with the family planning method they are using. 03 percent of them like to change the family planning method 60 percent of respondents do not prefer other methods of family planning.

\begin{tabular}{|c|l|c|c|}
\hline & Use of family planning method & No. Respondents & Percentage \\
\hline 1 & Satisfaction & 37 & $37 \%$ \\
\hline 2 & Like to change & 03 & $03 \%$ \\
\hline 3 & Non-preference Of other methods. & 60 & $60 \%$ \\
\hline
\end{tabular}

Table 4: Distribution (\%) of the respondents use of family planning methods

CONCLUSION: The current age of the respondents is between 15-44 years. Most of the respondents are agriculture labor women (100\%) as agriculture is the primary occupation. The respondent's level of education is low or illiterate. There are few respondents who had done matric. 21 percent of respondents done primary education. The highest percentage of the respondents' income is in the range of Rs. 20, 001-25, 000.

The study reveals knowledge and favorable attitude towards family planning. The knowledge of family planning is widespread among the respondents and are aware of least one method of contraception. Female sterilization or tubectomy is more popular among the women. The respondents are satisfied with family planning with 60 percent. It is through friends that the respondents have come to know about the family planning method.

\section{REFERENCES:}

1. Ministry of Health and family welfare, Family welfare programme in India year book, 1989-89, New Delhi; Government of India. 1990.

2. Dabral S. Malik SL. Demographic study of Gujjars of Delhi: IV. KAP of Family planning. J Hum Ecol.2004; 16 (4): 231-237.

3. Bhat PNM. Contours of fertility decline in India. A district level of study based on the 1991 census.

4. Ramesh B.M., Gulati SC, Retherford RO. Contraceptive use in India 1992-93. IPS: Mumbai and Honolulu, East-west center, National family Health survey Subject Report N0.2. 1996.

5. D. Kongawad. Awareness of family planning among the agriculture labor women: a study of Batakurki village. Indira R. Behera D.K. editors, Gender \& society. Vol-II, New Delhi vedamse Book (p) Ltd. 1999.

6. Gautam AC, Seth P.K. Appraisal of the Knowledge, attitude and practices (KAP) of family control devises among rural Rajputs and scheduled caste of Hatware area of Bilaspur district, Himachal Pradesh. 2001; Anthropologist, 4 (4); 289-292

7. Takkar N, Goel P, Saha PK, Dua D. Contraceptive practices and awareness of emergency contraception in educated working women. India J Med Sci (serial online) 2005. (Cited 2007 Apr 4), 59: 143-149.

8. Amonker RG, Brinker GD. The level of development and knowledge, attitude and practice of family planning in India, social development Issues, 200; 23(2).

9. Rao AAK. Client Demand Approach (CDA) in the Revised Family welfare programme- A Feasibility study Regional Health Forum who south East Asia Region, 2005: 5 (2). 


\section{ORIGINAL ARTICLE}

10. A Dharmalingm. S. Philip Morgan and Sowmya Rajan. Replacement Fertility in India: An analysis of the proximate Determinants of low fertility. Presented in Session 176: Perspectives on Fertility in Asia at Population Association of America 2012, Annual Meeting Program; San Francisco CA May3-5.

\section{AUTHORS:}

1. Drakshayani P. Kongawad

2. G. K. Boodeppa

\section{PARTICULARS OF CONTRIBUTORS:}

1. Research Scholar, Department of Sociology, Karnatak University, Dharwad.

2. Professor \& Chairman, Department of Sociology, Karnatak University, Dharwad.

\section{NAME ADDRESS EMAIL ID OF THE} CORRESPONDING AUTHOR:

Dr. Drakshayani P. Kongawad, C/o. M.H. Bellad, Ravi Kiran Building, Siddeshwar Nagar, $4^{\text {th }}$ Cross, Sainagar, Hubli - 31.

E-mail: drakshyani1981@gmail.com

Date of Submission: 22/01/2014. Date of Peer Review: 23/01/2014. Date of Acceptance: 08/02/2014. Date of Publishing: 19/02/2014. 